研究課題別評価

1 研究課題名: 体外からの刺激情報伝達によるナノデバイスの機能制御

2 研究者氏名: 青柳 隆夫

3 研究のねらい:

死亡原因としての悪性腫瘍 (ガン)の割合は、最近の医学の進歩にもかかわらず年々増加し ており、治療後の社会復帰などを考慮した低侵襲治療の重要性が高まってきている。放射線療 法や温熱療法などが知られており、化学療法と組み合わせることによりその効果を増強させる ことが報告されている。本研究では、ヒステリシス損失によって発熱することが知られている磁 性ナノ微粒子および敏感に応答する温度応答性材料を組み合わせることによって、温熱療法と 化学療法を同時に実現する温度応答性ナノデバイスを構築した。現在臨床的に応用されている ハイパーサーミアのように体外から加温させるのではなく、外部からのリモートコントロールが可 能な交流電流による誘導磁場を利用した。さらに、この誘導磁場による発熱によって局所的な 温熱効果を発揮させ、その発熱を刺激(情報)として薬物の制御放出を行わせるシステムであ る。

4 研究成果:

1.ナノ磁性微粒子表面の改質とキャラクタリゼーション

市販のマグネタイト磁性微粒子を入手し、TEMおよびXRDにより評価した結果、約 $130 \mathrm{~nm}$ 程 度の比較的球形に近いマグネタイト磁性微粒子であることを確認した。 3-aminopropyltrimethoxysilane を用いたシランカップリング反応によりこのナノ磁性微粒子の表 面に化学反応が可能なアミノ基を導入した。反応前と比較して、反応後に新たに $\mathrm{Fe}-\mathrm{O}-\mathrm{Si}$ 結合 が XPS 測定により確認されたことから官能基の導入を確認した。

\title{
2. 温度応答性高分子材料の調製と評価
}

本研究では、温度応答性高分子として水和一脱水和を可逆的に生起するイソプロピルアクリ ルアミド(IPAAm)を基本とする共重合体(図 1参照)と、結晶一融解現象を利用できるポリ( ロラクトン)(CL)について追究した。IPAAm ベースの共重合体については、磁性微粒子表面のア ミノ基との反応を行うために、カルボキシル基を導入したイソプロピルアクリルアミド共重合体を 2-カルボキシイソプロピルアクリルアミドを用いて調製した。この共重合体は重合性基の化学構 造が同一であるために反応性比が等しく、カルボキシル基が均一に分布した理想共重合体と なることが期待された。Kelen-Tudas法によって実際にその反応性比を評価した結果、ほぼ等し い反応性を確認することが出来た。

一般に固体表面への固定は温度応答性高分子の転移温度を変化させることが知られており、 駆動温度の調製を行う必要が出ることが考えられた。そこで、非イオン性の類似ポリマーとして 
2-ヒドロキシイソプロピルアクリルアミド(HIPAAm)と IPAAm との共重合体の調製を行った(図1参照)。この 共重合体においては HIPAAm モノマーの導入率にした がってほぼ比例的に転移温度が上昇することが確認 された。すなわち、ナノ磁性微粒子表面への固定化す るポリマーの駆動温度をこのモノマーの導入率で制御 出来ると考えられた。このモノマーは非イオン性であり、 イオン的な相互作用での薬物固定化を想定している のでそれらには影響しないものと考えられた。

PCL については、ポリマーの性質としてその転移温 度が $60^{\circ} \mathrm{C}$ 付近と生体系での利用を考慮すると高過ぎ<smiles>CCCCCCCCCC(=O)NC(C)CC(C)C</smiles>

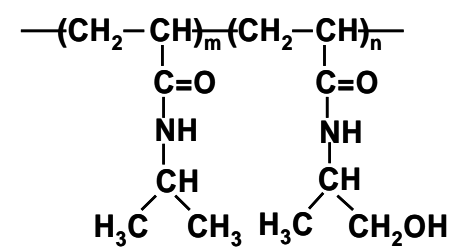

図 1 ポリイソプロピルアクリルアミド誘導体 の化学構造

るために、生体付近で駆動させるための研究を遂行した。鎖長と分岐数を制御して架橋構造を 導入することにより、結晶性を制御し、その結果として駆動温度を体温付近に近づけることが出 来た。

3. 温度応答性高分子固定化と得られたナノ磁性微粒子のキャラクタリゼーション

ナノ磁性微粒子表面のアミノ基とカルボキシル基を有する IPAAm共重合体とを縮合剤を用いて化学結合させた。反応の進 行は、XPSにより追跡しアミド基に起因する $\mathrm{N}_{1 \mathrm{~s}}$ のピークの増大が 観察された。さらに、TEMによる形態観察を行ったところ、磁性微 粒子表面に10〜20nm程度の高分子層が確認された。この層は ナノ磁性微粒子にほぼ同程度の厚さであり、 entanglementを起こ してゲル薄膜様の構造になっていると考えられた。

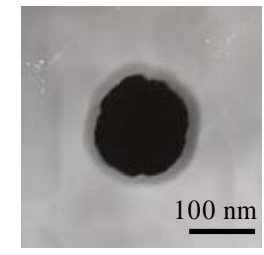

图 2 温度応答性高分子固定化 ナノ磁性微粒子のTEM写真

4. 温度応答性高分子固定化ナノ磁性微粒子の刺激応答性評価

安定な IPAAm ベースの温度応答 性高分子層の固定化を確認するため に、この高分子の良溶媒あるいは貧 溶媒中での微粒子の分散安定性を 評価した。その結果、ポリマーの貧溶 媒である $\mathrm{n}$-ヘキサン中では微粒子の 早い沈殿形成が確認された。固定化 に関与しなかったカルボキシル基は ナトリウム塩となっているために、水 中での長時間にわたる分散安定性が 確認された。さらに、この微粒子の温 度応答性を評価した(図3参照)。固

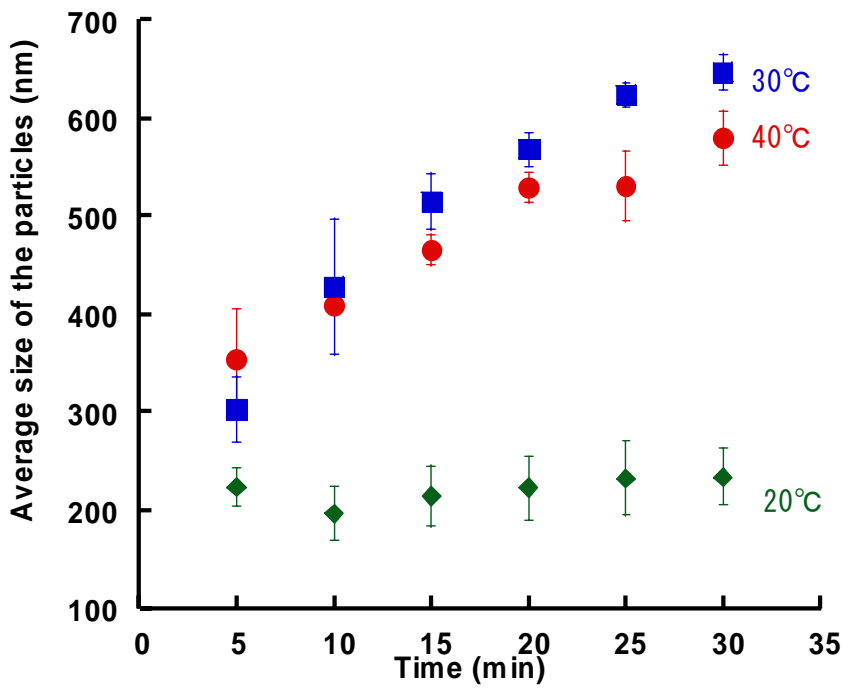

図 3 温度応答性高分子を固定化したナノ磁性微粒子 各温度の粒径変化 
定化に用いた温度応答性高分子は、 $100 \mathrm{mM}$ の NaCl が含む水溶液中で $27^{\circ} \mathrm{C}$ 付近に相転移温

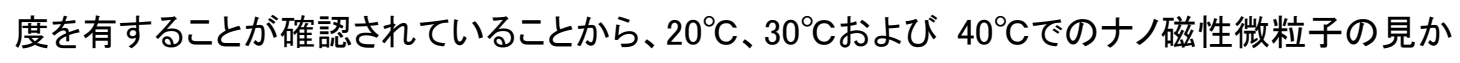
けの粒径変化を動的光散乱測定装置により評価した。その結果、温度応答性高分子の相転移

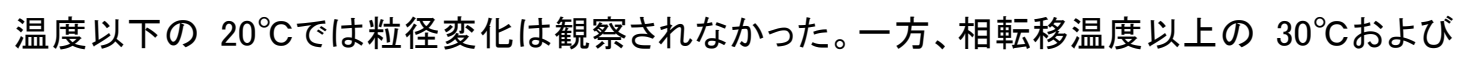

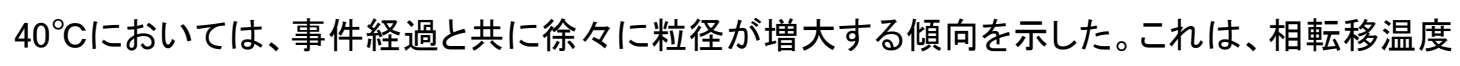
以上で温度応答性高分子が脱水和して疎水化したために疎水性相互作用によって磁性微粒 子同士が凝集したためであると考えられた。すなわち、化学固定しても温度応答性高分子が機 能したことを示している。

さらに、誘導磁場内での温度応答性何磁性微粒子の挙動を追究した(図4参照)。すなわち、 疎水性のオクタデシル基を表面に修飾したシリカ粒子を、カラムに充填し、交流磁場が発生す るコイル内に固定した。これに温度応答性磁性ナノ微粒子分散液を流した。交流磁場を発生さ せない場合は、ナノ磁性微粒子がそのまま流出してきたが、交流磁場を発生させると、ナノ磁 性微粒子がカラム内に滞留することが判った。これは、ナノ磁性微粒子が交流磁場に応答して 表面が疎水化し、疎水性表面と相互作用したためである。これは、ナノ磁性微粒子が誘導磁場 によって発熱し、その熱が微粒子表面に伝わりその結果、脱水和を引き起こし疎水化したこと を示している。

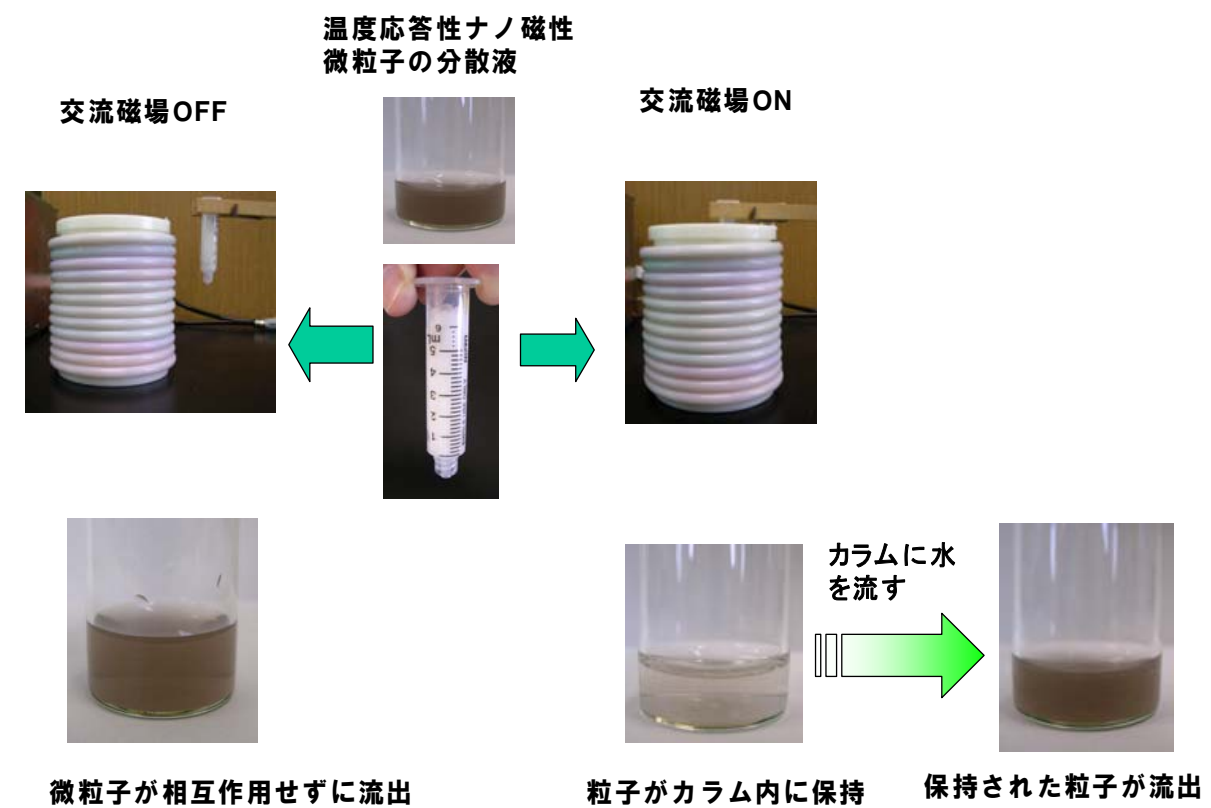

図 4 交流磁場に応答した温度応答性ナノ磁性微粒子の流出挙動

5. 抗ガン剤の固定化と薬物放出制御

温度応答性高分子の固定化反応に関与しなかったカルボキシル基を利用してアミノ基を有する ドキソルビシン静電的な相互作用で固定化を試みた。高分子の固定化の際に、縮合剂のモル 比を変化させて未反応のカルボキシル基を残存させ、その官能基を利用した。固定化後の薬 物濃度を測定した結果、カルボキシル基の残存率が高いほど薬物の固定化量が多くなることを 見いだした。さらに、抗ガン剂を固定化した温度応答性ナノ磁性微粒子を温度応答性高分子の 
相転移温度前後の水中に分散させたところ、相転移温度以上で薬物の放出が確認された。す なわちイオン的な相互作用をしていたカルボキシル基が高分子の脱水和によってその解離度 が低下してしまったために薬物を放出させたものと考えられた。

5 自己評価:

研究当初、磁性微粒子表面への温度応答性高分子の固定化はそれほど困難であると予 想しなかったが、マグネタイト表面へのシランカップリング試薬の反応性が想定していた以上 に悪く、さらにその確認に大幅に手間取ってしまったために多くの研究時間が割かれてしまっ た。しかし、その後、固定化反応に成功し、これまで得ていていた温度応答性高分子の知見 に基づいた予想通りに、ナノ磁性微粒子への固定化後も敏感な温度応答挙動を発現するこ とを見いだすことが出来た。交流磁場に応答した温度応答挙動、抗ガン剂の固定化さらには 温度変化に応答した放出挙動も確認することが出来た。最終年度は培養細胞での効果の確 認まで行う予定であったが時間が不足してしまったのは反省点である。

磁性微粒子と敏感な温度応答性を示す概念は、JSTサテライト宮崎が募集した「実用化の ための可能性試験(FS)」に採択され、研究をスタートさせることが出来た。また、別の用途とし て遺伝子デリバリ一用の担体としての可能性も見いだすことが出来た。

また、当初検討した温度応答性高分子として結晶融解型のポリカプロラクトン系材料を用 いて、体温付近で駆動することが出来る材料設計に成功した。今後、磁性微粒子との混み合 わせによって、新しい磁場応答性の新しい材料展開が可能である。

6 研究総括の見解:

磁性微粒子に交流磁場をかけて加熱し, 薬品を放出してがん治療を行なうことは面白いアイ ディアであり、磁性微粒子に吸着して相転移を起こす高分子を見つけたことは評価できる。し かし、これからはナノ磁性微粒子の腫瘍細胞へのアクティブターゲティングを現実化すること が必要である。薬物の放出を確認する成果がえられているが、磁性ナノ微粒子を加熱する誘 導磁場を発生するのに大きな電力を必要としている。材料や周波数などの最適化と動物実 験などで実用化に向けた研究をさらに進めることが期待される。

7 主な論文等:

論文:

1. T. Kanda, K. Yamamoto, T. Aoyagi, "N-Isopropylacrylamide-based Temperature-Responsive Polymer with Carboxyl Groups for Controlled Drug Release", Journal of Photopolymer Science and Technology, 18(4), 515-518(2005)

2. K. Uto, K. Yamamoto, S. Hirase, T. Aoyagi, "Temperature-responsive cross-linked 
poly $(\varepsilon$-caprolactone $)$ membrane that functions near body temperature",

Journal of Controlled Release, 110, 408-413(2006)

3. H. Wakamatsu, K. Yamamoto, T. Aoyagi, "Preparation and Characterization of Temperature-Responsive Magnetite Nanoparticle Conjugated with N-Isopropylacrylamide-based Functional Copolymer", Journal of Magnetism and Magnetic Materials, in press

4. T. Maeda, T. Kanda, Y. Yonekura, K. Yamamoto, T. Aoyagi, "Hydroxylated Poly(N-isopropylacrylamide) as Functional Thermo-responsive Materials",

Biomacromolecules, in press

(総件数 4 件)

特許:

1）複合微粒子およびその製造法（出願番号2004-245844）

2) 同PCT出願 (PCT/JP2005/115451)

(総件数 2 件)

招待講演:

1. T. Aoyagi, "Stimuli-responsive materials for Nano- and Microtechnology", The Forth International Symposium on Advanced Fluid Information and The First International Symposium on Transdisciplinary Fluid Integration, Nov. 11, 2004, Sendai Japan

2. 青柳 隆夫, “刺激応答性高分子の分子設計とその応用”, 第3回高分子医療研究会, 物 質·材料研究機構, 2005 年 1 月 31 日, つくば市

(総件数 2 件) 